\title{
Stroke Rehabilitation based on Cortical Plasticity and the Stage Theory of Motor Output Reorganization
}

\author{
Hiroyoshi Hara, M.D. ${ }^{1)}$ \\ 1) Division of Rehabilitation Medicine, Center of Stroke and Neurology, Aizawa Hospital
}

One of the most important objects of stroke rehabilitation is motor recovery from acute stage to chronic stage. Early rehabilitation intervention after stroke onset should be started during the critical time window phase. Herein, a theory concerning motor circuit reorganization in the cerebral cortex contributing to recovery following stroke is proposed. In the acute stage, motor recovery depends on residual corticospinal tract excitability from onset to 3 months (1st stage recovery). In the next stage, alternative output systems are used according to intracortical excitability depending on intracortical disinhibition at the peak of 3 months (2nd stage recovery). At 6 months and beyond training-induced synaptic strengthening becomes better established, and new networks are better reorganized (3rd stage recovery). Stroke rehabilitation programs commencing from the acute stage are required according to this stage theory. With each stage, selecting and performing the most effective rehabilitation programs is essential to successful recovery. Two motor recovery obstruction factors are indicated. One of them is Wallerian degeneration of the corticospinal tract. Early Wallerian degeneration of the corticospinal tract that is seen on diffusion-weighted MRI was reported. With the appearance of Wallerian degeneration at the acute stage, more attention should be directed to motor recovery inhibition. The second obstruction factor is the development of spasticity from the acute stage. Spastic paresis over time leads to immobilization of the paretic body part and chronic disuse of the paretic body part, which are avoidable through early rehabilitation intervention. Recently, various interventions were proposed for motor recovery dependent on the cortical plasticity theory. The combination of repetitive transcranial magnetic stimulation and intensive occupational therapy (NEURO-15) reported by Abo (2010) are recommended to recover hand functions at the chronic stage as 3rd stage recovery. The NEURO-15 is a promising method for stroke rehabilitation.

(Received March 22, 2012 ; accepted April 23, 2012)

Key words : stroke rehabilitation, cortical plasticity, motor output reorganization, critical time window, transcranial magnetic stimulation

Jpn J Neurosurg（Tokyo）21:516-526, 2012

\section{はじめに}

脳卒中リハビリテーションの最大の関心事は, 脳卒中
により生じた運動麻痺の軽減と失われた運動機能の回復 である，現在までに，脳科学理論に依拠した多くの運動 麻痺回復のための知見とリハビリテーションの system-

連絡先：原 寛美， テ390-8510 松本市本庄 2-5-1 相澤病院脳卒中脳神経センターリハビリテーション科 Address reprint requests to: Hiroyoshi Hara, M.D., Division of Rehabilitation Medicine, Center of Stroke and Neurology, Aizawa Hospital, 2-5-1 Honjou, Matsumoto-shi, Nagano 390-8510, Japan 
atic review が報告されてきている.今日, 脳卒中リハビリ テーションは臨床上の経験論ではなく，明確化されてき ているエビデンスに依拠した治療の方法論が導入される 時代に入ったと言える。本稿は，可塑性理論に依拠した 脳卒中運動麻痺回復リハビリテーションの review と, 臨 床場面へのその適用について自験例をふまえて概説し た.

\section{今日までに明らかにされている脳可塑性理論 \\ 11 健常動物実験における大脳可塑性 Cortical Plasticity}

リハビリテーション介入手法が大脳皮質の可塑性に寄 与することを最初に示したのはNudo らであった。健常 ラットの実験において食物の入った皿を拾う巧緻性を要 する訓練により，微小電極で検出された背側運動野にお ける手指と手関節の支配領域（cortical map）は，巧緻性 を要さない訓練群に比して有意に拡大し, 肘と肩関節の 支配領域は減少することを示した ${ }^{21)}$ 。運動の巧緻性学習 の手法が，運動野の cortical map を変化させうることを 初めて明らかにした。同様に Nudo はリスザル (squirrel monkey）の実験に扔いて，小さな対象物を手指にて摘み 上げる訓練を課すことで，手指の運動野支配領域が拡大 し，一方手関節と前腕の運動野支配領域は縮小すること を示した。ささら前腕回内外訓練を課すと，前腕の支配 領域が拡大，手指のそれは縮小した。この結果は一次運 動野 M1においては上肢の使用方法により cortical map が絶えず変容をとげうることを示している。この現象を Nudo は Use-dependent alterations of movement representations in primary motor cortex と命名した ${ }^{29)}$ 。こうし た学習により惹起される運動野の可塑的変容は人間にお いても確認されており，ピアノ練習により反対側一次運 動野 M1 に扔ける手指支配領域の搪大が認められてい $3^{32)}$.

さらに運動野の可塑的変容は訓練の特性にも依存する ことが指摘されている.訓練するスキルに特異的であり， 学習 (motor learning) を惹起しない単なる運動のアク ティビティでは起こらないことも特徵である21)．また運 動野の拡大の程度は学習の成功の度合いに相関してい る28)，つまり運動野の可塑性にとり運動学習がいかに成 功するかが肝要となっている。こうした知見がリハビリ テーションにおける課題志向的訓練 (task-oriented training）の理論的基盤となっている.

\section{2 脳梗塞モデルにおける知見}

Nudo らは虚血脳梗塞 squirrel monkey のモデルにお いて, 虚血後に特別な訓練介入がなされなければ 1 力月 後には手指の運動野支配領域は 50\%以上減少したこ と ${ }^{30)}$ ，しかし機能回復訓練をデザインすることで手の支 配領域の減少を阻止しえることを明らかにしている ${ }^{31}$. このデザインされた機能回復訓練方法とは健側肢を抑制 し，患側肢の使用を促す手法であり，のちに constrainedinduced movement therapy（CIMT あるいはCI 療法）と 称せられるようになった手法である7114222.

\section{3 リハビリテーションにおける critical time window の概念}

動物の虚血モデルにおいては，リハビリテーションの 介入時期が早いほど，その効果が高いことが支持されて (る ${ }^{4) 5}$. 脳梗塞発症後のほぼ数週以内には組織的な修復 が生じており,この動的再構築の時期には, 治療的介入 に鋭敏に反応する。この時期に効果的なリハビリテー ションの介入がされれば可塑性への相乗効果として期待 される ${ }^{30)}$. しかし発症 1 力月以後からの遅延介入では手 の運動野支配領域の萎縮が生じてしまうことが明らかに されている ${ }^{3)}$. つまり脳梗塞発症の初期 $2 \sim 3$ 週以内が critical time window とされ，この時期のリハビリテー ションの早期介入により運動野の可塑的再組織化を最大 限に引き出すことが可能となることが明らかにされてい る.

\section{4] 臨床における脳卒中リハビリテーションの効 果と介入時期}

脳卒中リハビリテーションの臨床的な効果と介入時期 に関しては, Wagenaar ら ${ }^{41) 42)}$ により古くは systematic review がなされている。 そのなかで発症後 1 週以内に, 1.5 倍量のリハビリテーションの介入が運動麻痺の改善 に有意に効果的であることが明らかにされている。脳卒 中リハビリテーションでは早期開始と訓練時間の多寡が 麻痺の改善を左右することが支持されており, dose response recovery あるいは dose response relationship と いう概念が浸透し 20 年余が経過している. その後リ八 ビリテーションの強度は日常生活動作 ADL を改善する ことが明らかにされた ${ }^{24)}$. しかし現在までに運動機能の 改善, こと上肢機能の改善は, 早期介入とともにリハビ リテーションの手法に左右されていることが明らかと なってきている25)。つまり運動麻痺の改善にはリハビリ テーション時間の多室だけではなく，いかなるリハビリ テーションプログラムを，急性期から慢性期にかけての 


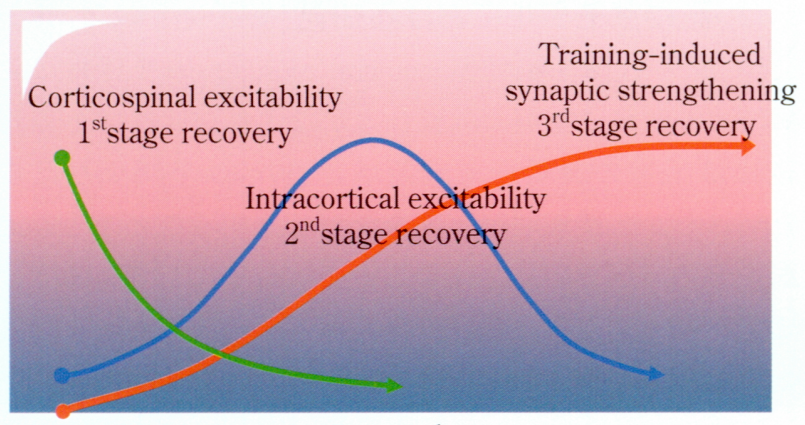

Acute stage

3 months

6 months

Fig. 1 Motor output reorganization schema after stroke $^{30}$. In the acute period corticospinal excitability influences motor recovery. At the peak of 3 months, intracortical excitability contributes to motor recovery. An alternative output system is used as necessary. At 6 months and beyond new networks are established in proportion to training-induced synaptic strengthening. (Copyright (C) H. HARA)

ステージ別に的確に選択し導入していくかが問われる時 代となっていると言える.

\section{運動麻痺回復のステージ理論}

運動麻痺改善に向けたリハビリテーションプログラム は, 急性期からの回復メカニズムに依拠して選択される 必要性がある。

今日脳卒中後の機能回復メカニズムを説明する神経回 路再組織化に関する知見が明らかにされている。その一 つに脳卒中発症後の経時的な運動麻痺回復中枢神経再組 織化のステージ理論がある (Swayne ら， 2008） ${ }^{36)}$.

それによると急性期の回復メカニズムは残存している

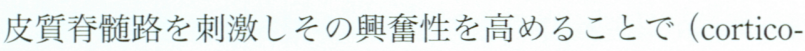
spinal excitability), 麻痺の回復を促進する時期となる (1st stage recovery)。そしてその興奮性は急性期から急 速に減衰して 3 力月までには消失する。つまり急性期に おいて運動麻痺を回復させることができるリハビリテー ションは，いかに効果的に残存している corticospinal excitability を刺激できるか否かが問われる。限局する皮 質下の梗塞・出血病変においては, 残存している皮質春 髄路の興奮性を効果的に刺激するリハビリテーションが 実施されるならば,この 1st stage メカニズムにより運動 麻痺の回復が完結する可能性が示唆される.

次のステージは，皮質脊髄路の興奮性に依拠するので はなく, 皮質間の新しいネットワークの興奮性 (intracortical excitability）に依拠する時期であり，3 カ月をピーク
にこのメカニズムが再構築される (2nd stage recovery). この時期は皮質間の抑制が解除される (disinhibition) こ とにより生じる回復メカニズムが機能する。代替出力と しての皮質ネットワークの再組織化（reorganization）が 構築され，残存している皮質清髄路の機能効率を最大限 に引き出す中枢指令として機能する。つまり大脳での組 織的再構築がなされる時期である。 そしてこの disinhibitionのメカニズムはやはり 6 カ月までには消失するた めに，再組織を促すリハビリテーションプログラムをこ の時期までに検討し成果を引き出すことが求められると 言える.

その後 6 力月以後も持続して徐々に強化される機能 は,リハビリテーションにより惹起されるシナプス伝達 の効率化 training-induced synaptic strengthening である とされる (3rd stage recovery)。つまり 2nd stage により 再構築された新しい代替のネットワークにおいてそのシ ナプス伝達が効率化されることにより出力のネットワー クが一層強化され，そして確立される時期であると結論 される (Fig. 1).

2nd stage および, 3rd stage においては, 随意運動出力 としての新しいネットワークが要求される時期に移行し ており，そのような出力ネットワークの再構築が形成さ れるべくなされるリハビリテーションのプログラムが求

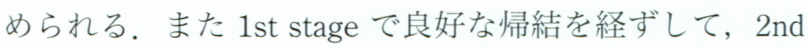
stage さらに, 3rd stage へと移行することはありえない. したがって急性期からのリハビリテーションの開始と連 続性, さらに stage 理論を意識したリハビリテーション プログラムの施行とその成否が求められる.

\section{ステージ理論に依拠したリハビリテーション プログラムを進めた症例の提示}

\section{症例 1 (Fig. 2, Fig. 3)}

Fig. 2 と Fig. 3 には左中大脳動脈下行枝閉塞例の MRI 画像と, 発症 6 週目の右上肢訓練場面を提示した。 初期には重度の右上肢麻痺であり, 右手指機能は完全麻 痺であった。随意性を引き出すために初期には電気刺激

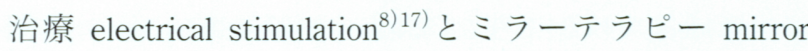
therapy ${ }^{27) 33}$ 46) にて随意性を引き出すリハビリテーショ ンプログラムを優先して施行した。結果的に皮質脊髄路 の興奮性を効果的に高めることが可能であった。それに より右上肢手指の随意性が惹起されて 6 週にて訓練用 の箸使用の反復課題訓練 repetitive task training $g^{6}$ が可能 となった。このケースでは急性期から効果的に皮質脊䯣 路の刺激に成功したことにより重度な上肢手指麻痺を改 

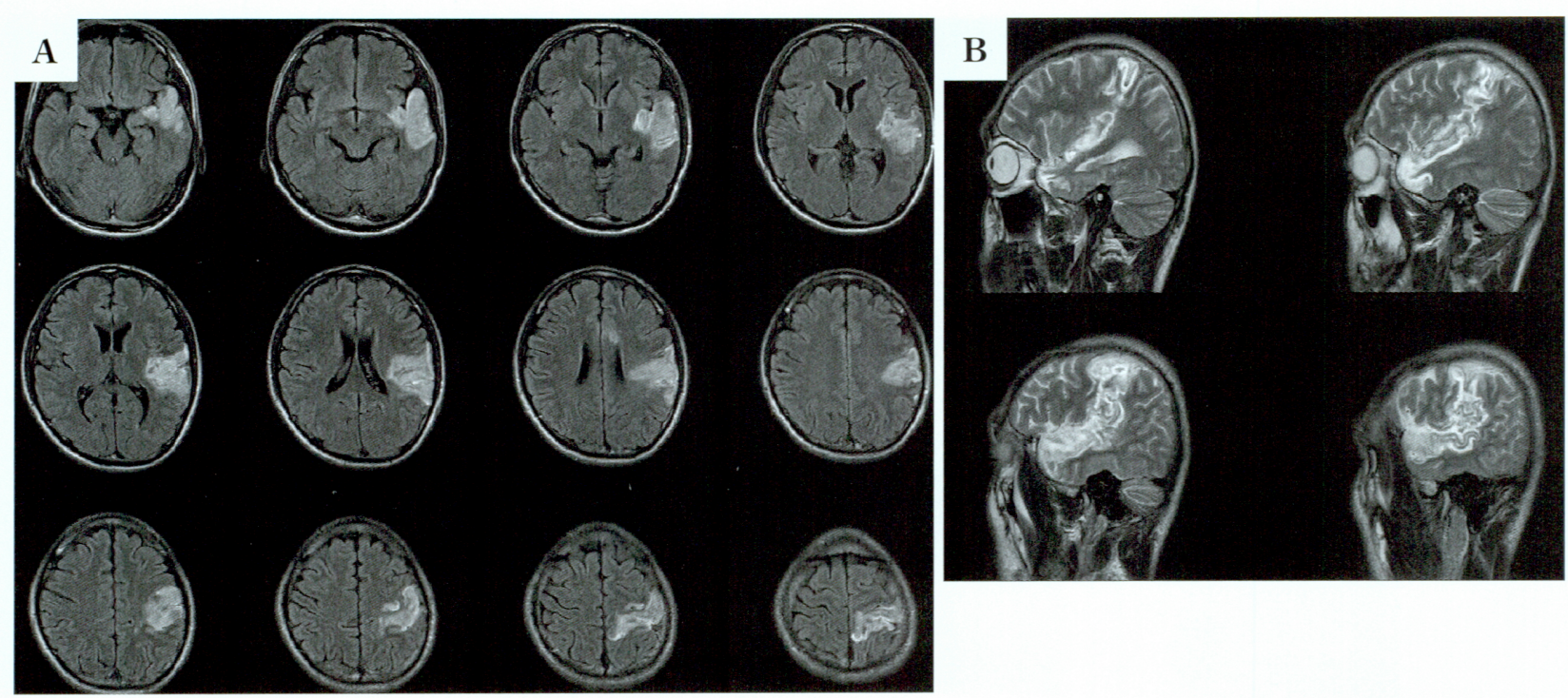

Fig. 2 Case 1: The MRI flair imaging demonstrates an acute infarction of the left MCA inferior branch area (A). The MRI T2 weighted sagittal imaging (B) demonstrates an acute infarction on the left temporal lobe and left parietal lobe (B).

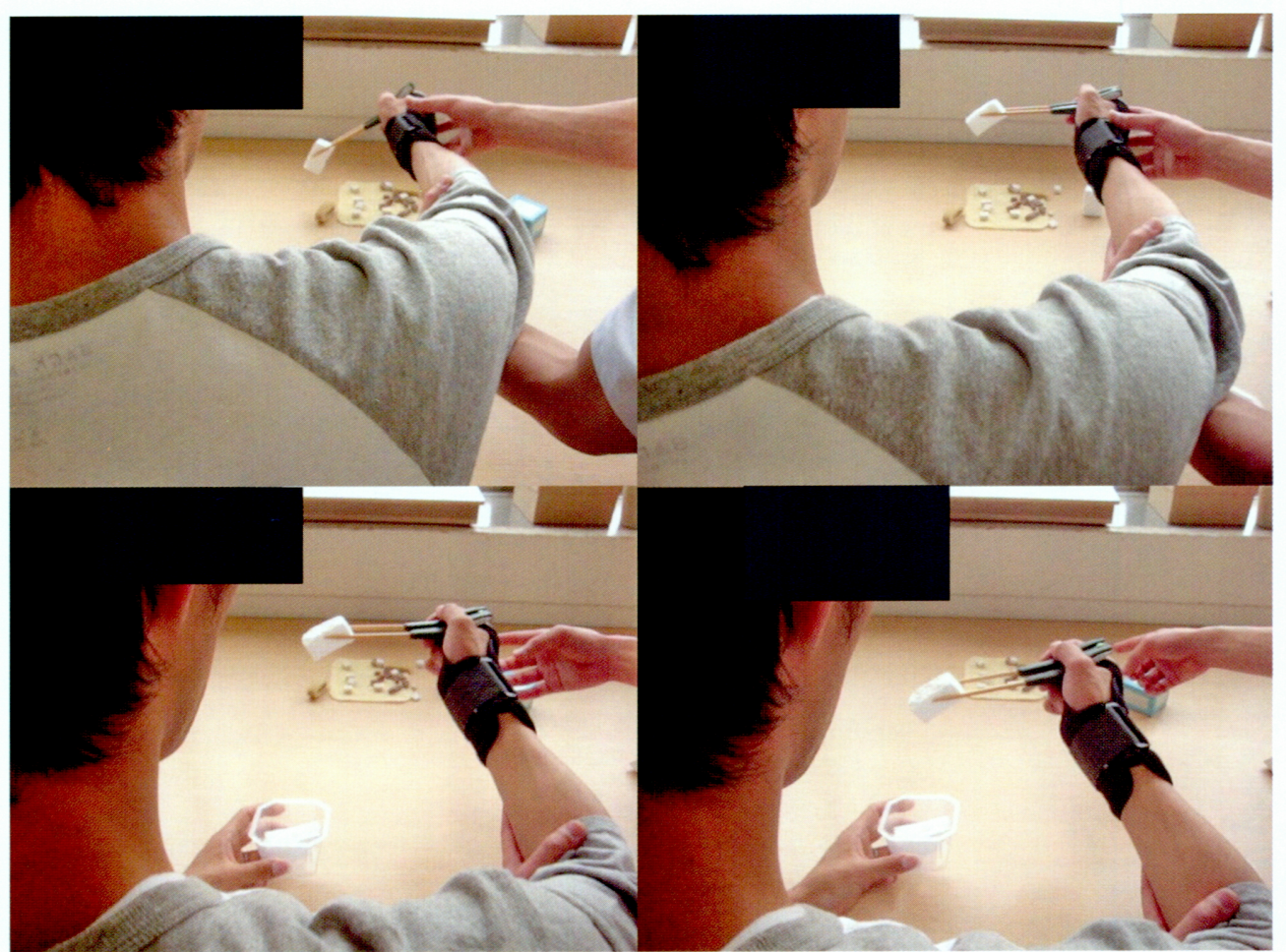

Fig. 3 Case 1 : The patient with the left MCA inferior branch occlusion exercises the affected right hand by repetitive task training to use chopsticks at 6 weeks. This task training corresponds to 2nd stage recovery.

善させることができ， 6 週までに麻痺側上肢手指での複 合動作としての task 訓練が可能な 2nd stage recovery に到達することができたと理解される。
脳卒中急性期からの電気刺激治療とミラーテラピーの 効果は, RCT にて検証されており ${ }^{8) 27)}$, その有用性が今 日では支持されている。 Fig. 4 には電気刺激治療の一つ 


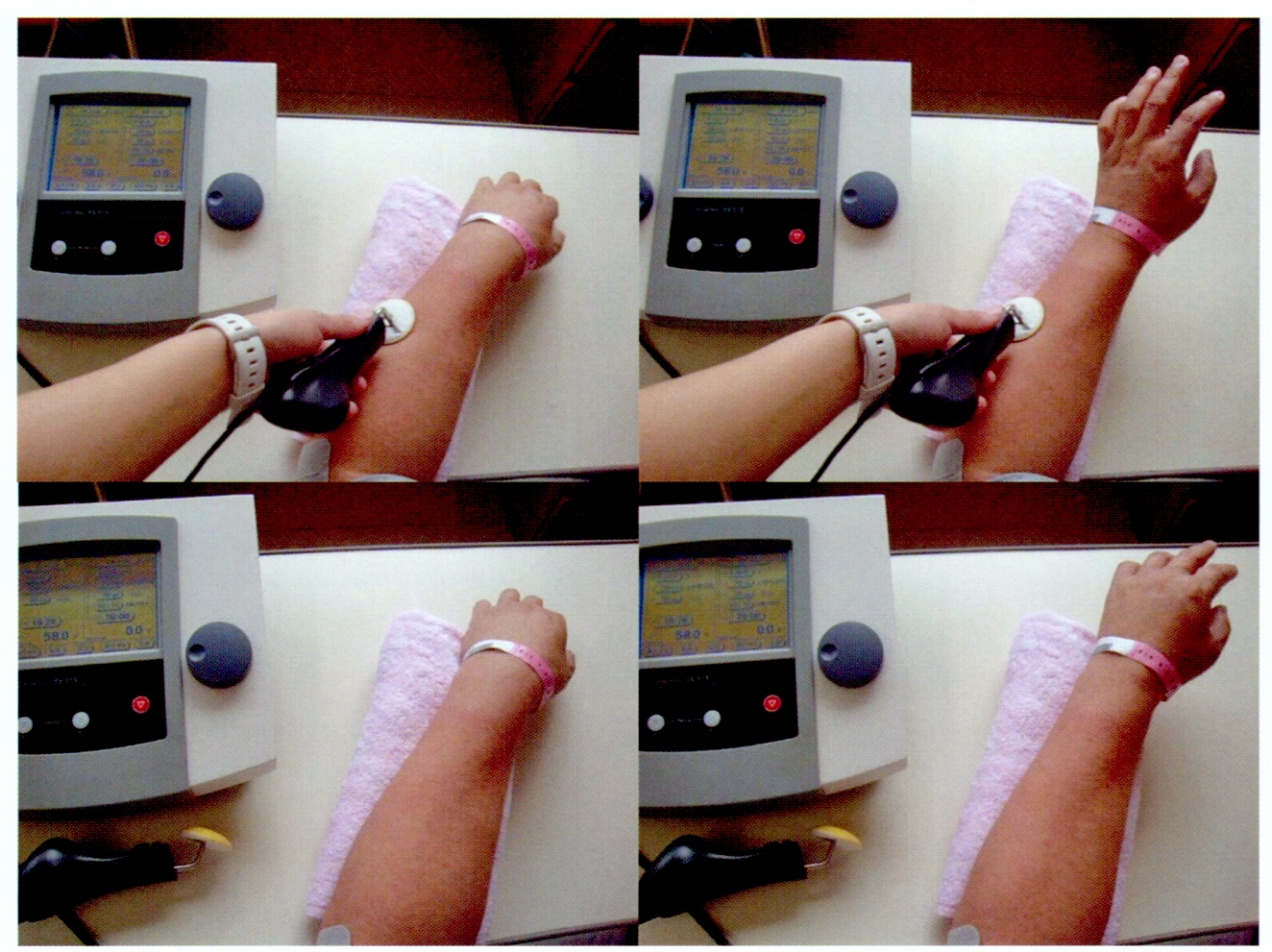

Fig. 4 High-voltage pulsed current therapy is one of the useful electrical stimulation therapies that can induce the reduction of skin impedance. The upper figures demonstrate that high-voltage pulsed current stimulation could induce extension movement of wrist and fingers on the paretic hand. The lower figures demonstrate active finger extension movement of the paretic hand after high-voltage pulsed current stimulation.

である高電圧パルス電流療法20)を示す。高電圧パルス電 流療法は, ツインピークパルス電流, 高電圧そして単相 波の特性を有しており，他の電気刺激よりも効果的に皮 膚抵抗を減少させて目的とする骨格筋の収縮を引き出す ことが可能である。そのため急性期から麻痺肢の刺激に 用いることにより, corticospinal excitability を引き出すこ とができ，さらに痓縮の予防と随意運動の誘発を可能と する。

\section{症例 2 (Fig. 5, Fig. 6)}

Fig. 5 と Fig. 6 には左中大脳動脈と前大脳動脈領域に 心原性脳塞栓症を発症した症例の急性期 MRI 拡散強調 画像と, 発症から 14 週目の右上肢手指の訓練場面を提 示した。初期には右上下肢は重度麻㽻を呈しており, 当 院での急性期リハビリテーションを経て, 回復期リハビ リテーション病院に転院をしている。 Fig. 6 は発症から 14 週における回復期リハビリテーション病院での右上 肢訓練場面である。右上肢での複合動作としてのブロッ ク積み木が可能となっており, 1st stage recovery を経て 2nd stage recovery に到達していることを示している。こ
のような異なる難易度の課題に取り組むリハビリテー ションプログラムが課題志向的訓練 task-oriented training ${ }^{15) 39)}$ とされ，2nd stage あるいは3rd stage におけ る随意運動回復に向けた新たなネットワークを形成する ことに寄与する。動物実験の知見でも明らかにされた成 功裡に繋がる課題の達成を選択することが, 脳機能可塑 性を引き出すことになる。

\section{運動麻痺回復を阻害するもの}

急性期からの運動麻痺回復のリハビリテーションを進 めていくうえで, その阻害となる 2 つの病理学的および 神経生理学的メカニズムが明らかにされている.

その1つは病変部位から下降する皮質脊髄路に生じ るワーラー変性であり, 脳卒中慢性期の MRI 画像により 検出される ${ }^{2326)}$. しかしこのワーラー変性は脳卒中発症 の第 7 病日にはすでに MRI 拡散強調画像（DWI：diffusion-weighted image）にて病変側大脳脚において高 intensity 所見として描出されることが明らかにされてい 


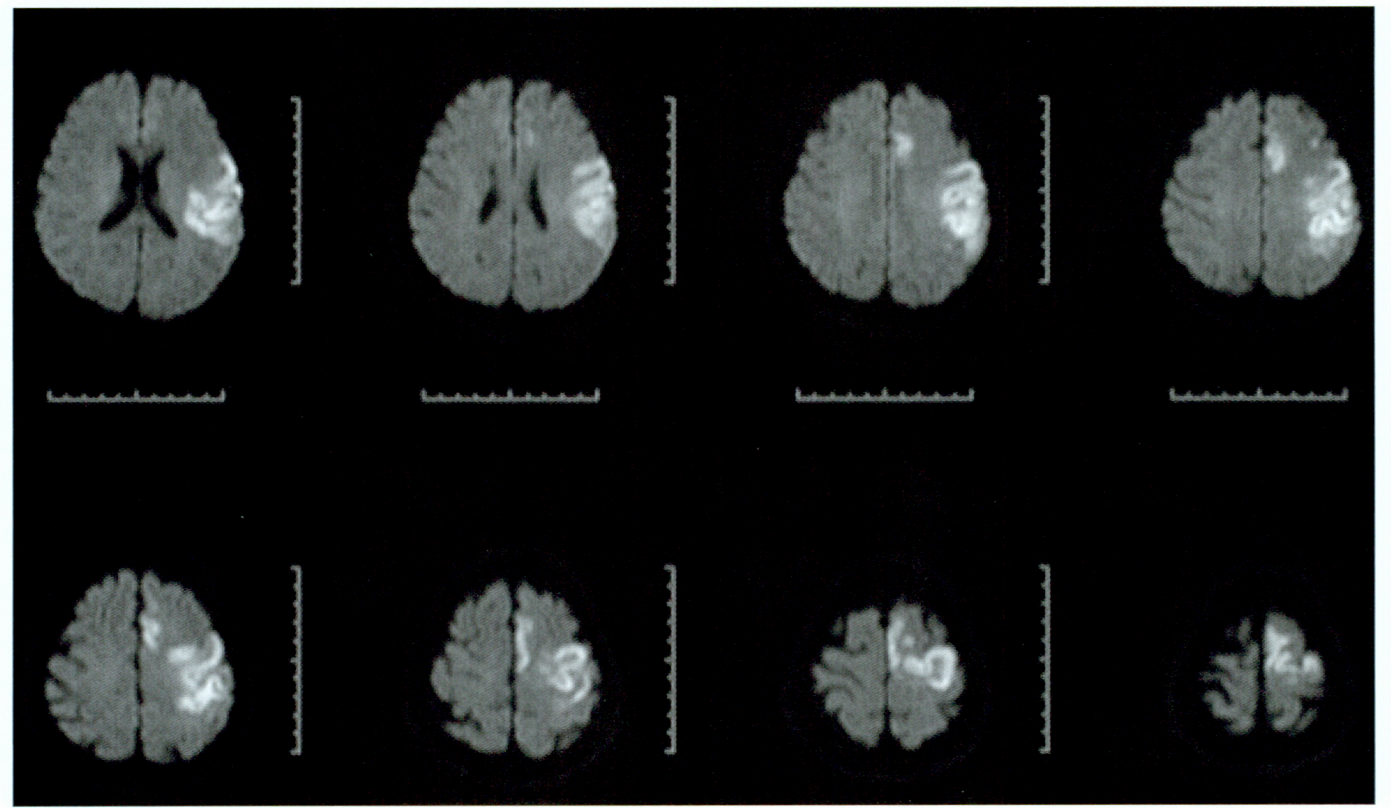

Fig. 5 Case 2: The MRI diffusion imaging demonstrates an acute infarction of the left MCA and ACA territory due to a cerebral cardiogenic embolism. This patient has severely impaired right hemiparesis and aphasia.

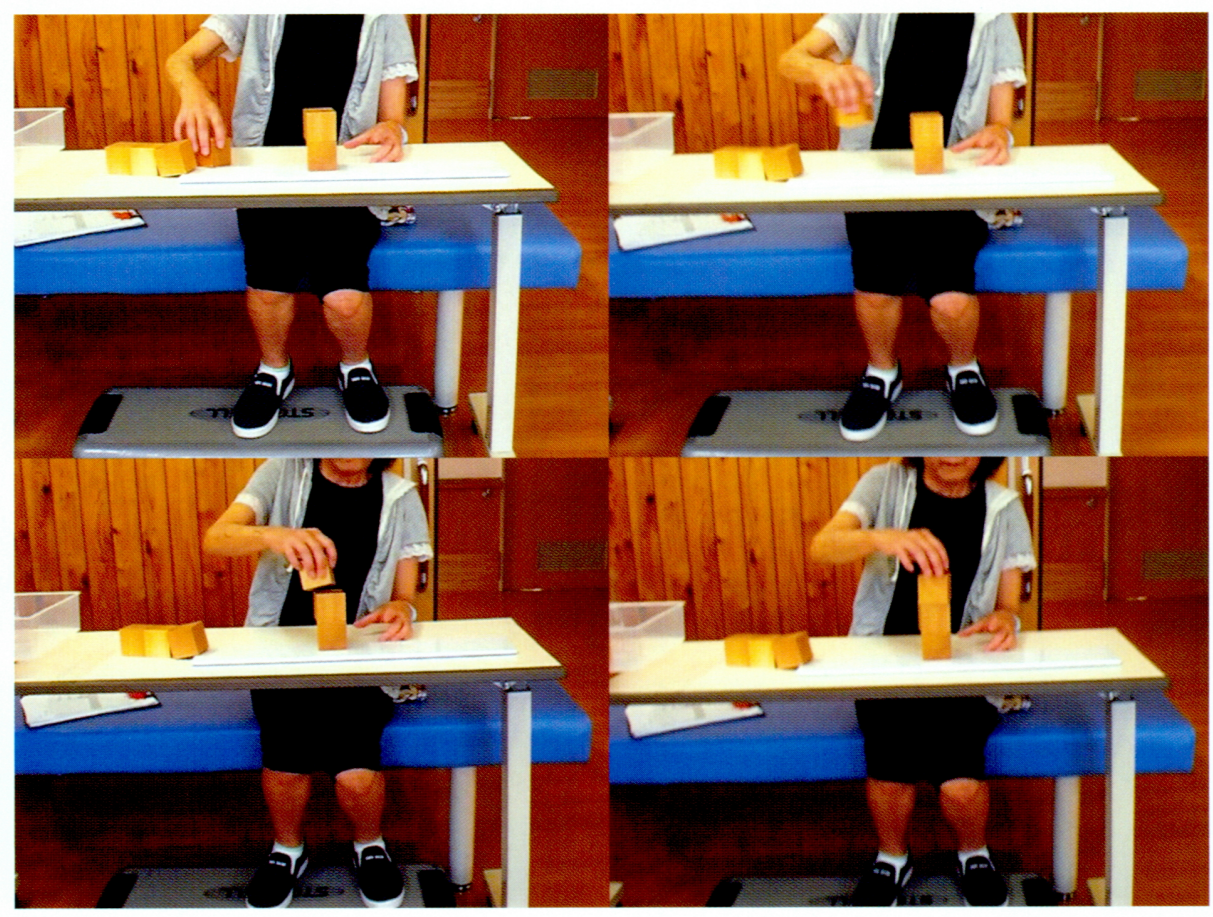

Fig. 6 Case 2 : The patient exercises the affected right hand by repetitive task training to build blocks at 14 weeks after onset in the convalescent rehabilitation hospital. This complicated task training corresponds to 2nd stage recovery. 
る.同部位における ADC (apparent diffusion coefficient)值 の減少は運動麻痺回復の予後不良の徴候となることも示 唆されている ${ }^{9)}$ 。一方でリハビリテーションの早期介入 による corticospinal excitability の刺激が，急性期から生 じるワーラー変性を阻止しえることになるか否か，その 点に関しての知見は現時点では明らかにはされていな い.しかし運動麻痺回復を阻害する皮質脊髄路のワー ラー変性が急性期から生じて進行している事実には着目 すべきである。

2 つ目は，麻痺肢に生じる病縮の発現に関する新しい 知見である. Gracies ${ }^{12)}{ }^{13)}$ は脳卒中発症直後には痤縮は生 じていないことを指摘し, その後に生じてくる㾏縮のメ カニズムを神経理学的論文の systematic review を行う ことで明らかにしている。それによると，発症後の麻算 肢においては構成する筋は短縮位でのポジショニングが なされており, さらに他動運動の介入遅延に起因する不 動化 immobilizationの結果，一層の筋繊維の短縮が惹起 され助長される。一方筋の生理学的メカニズムでは数時 間の不動化により筋繊維の変性が惹起され, 結合組織と 脂肪組織への置換が生じてくる。その結果麻痺肢骨格筋 はその弾性が失われ，錘内繊維内の筋紡錘の興奮性が増 大する。そのためにわずかな伸張刺激により筋紡錘は過 敏に反心し，深部腱反射の无進として具現する，それが 高じて痤縮へと伸展する。ささらに麻痺肢の不動化および 不使用は中枢神経の組織転換をもたらし，大脳皮質運動 野の萎縮 central disuse へとつながる.この中枢神経系の 退行変容と末梢における骨格筋変性が相まって痤縮さら に拘縮へと伸展することになる。この immobilization に より生じる痤縮の発現・増悪が運動麻痺回復の第二の阻 害因子となる。

しかし Gracies は麻痺肢における深部腱反射艺進を初 期の warning sign と捉えて, 急性期の不動化 immobilizationの時期からリハビリテーションが介入して, 瘥縮を 予防することが可能であることも指摘している.

今日痤縮に対する治療としてボッリヌス治療が可能と なり，脳卒中治療ガイドラインではグレード A と支持さ れている ${ }^{35)}$. 脳卒中発症後慢性期における痤縮に対して ではなく，亜急性期における疰縮発現の早期にボッリヌ ス治療を施行することが, 運動麻痺の長期予後の改善に 寄与することも明らかにされており ${ }^{34)}$, 痤縮に対する早 期介入がボッリヌス治療の側面でも支持されている.

\section{運動麻㾇回復のステージ別の リハビリテーションプログラム}

運動麻脾改善の効果的リハビリテーションとは, 前記 のステージ理論に依拠し,さらに 2 つの阻害因子の発生 を意識して, 発症直後の急性期からリハビリテーション の介入を集約し，しかもプログラムを的確に選択して効 果的・継続的に進めることである．脳卒中後の運動麻痺 に対する訓練プログラムの効果に関して systematic reviewがされている25). それによるとメ夕解析にてこと 上肢 $(\mathrm{arm})$ 機能の改善に有意差を認めるプログラムと しては, CI 療法7)14)16)22)45), EMG フィードバック，ロボ ティック訓練 ${ }^{2)}$ ，反復課題トレーニング，治療的電気刺 激などがあげられている。しかしこうしたプログラムが 急性期からのいかなるステージに適用することが効果的 であるかは明らかにされていない.そのために検討すべ きは, 1st stage から 3rd stage までのどのステージにい かなる訓練プログラムを選択することが妥当であるかで ある.CI 療法に関しては慢性期での有用性が明らかにさ れており ${ }^{16) 45)}$ ，ステージ理論上 2nd stage あるいは 3rd stage recovery の時期での適用と理解されるが，急性期 に適用した報告もあるが有用性は必ずしも明らかにはさ れてはいない10).

\section{経頭蓋磁気刺激 TMS と集中 OT (Neuro- 15 : novel intervention using repetitive TMS and occupational therapy-15 days protocol）による上肢手指機能の改善}

東京慈恵会医科大学りハビリテーション医学講座の安 保・角田による経頭蓋時期刺激 TMS と集中 OTを組み 合わせた手指機能改善プログラム (Neuro-15) ${ }^{1) 18)}$ は, 従 来のリハビリテーションだけでは限界のあった 3rd stage での麻痺側上肢手指機能回復をはかる方法論とし て特筆される．脳梁の交連繊維を介して健側大脳半球運 動野から患側大脳半球運動野に対する抑制が生じている 理論 ${ }^{43)}$ を背詈にしている。健側大脳半球手指運動野に対 して経頭蓋磁気刺激にて抑制をはかることで，運動機能 の可塑性を引き出す priming 効果を生じさせて, その後 集中的な作業療法 OT での上肢手指機能改善をはかる 15 日間の入院による斬新なりハビリテーションプログ ラムである. 当院も共同研究施設として Neuro-15を開 始し, 従来のリハビリテーションでは上肢手指麻痺機能 改善はプラトーとみなされていた慢性期患者の上肢手指 機能改善に効果を確認している。 


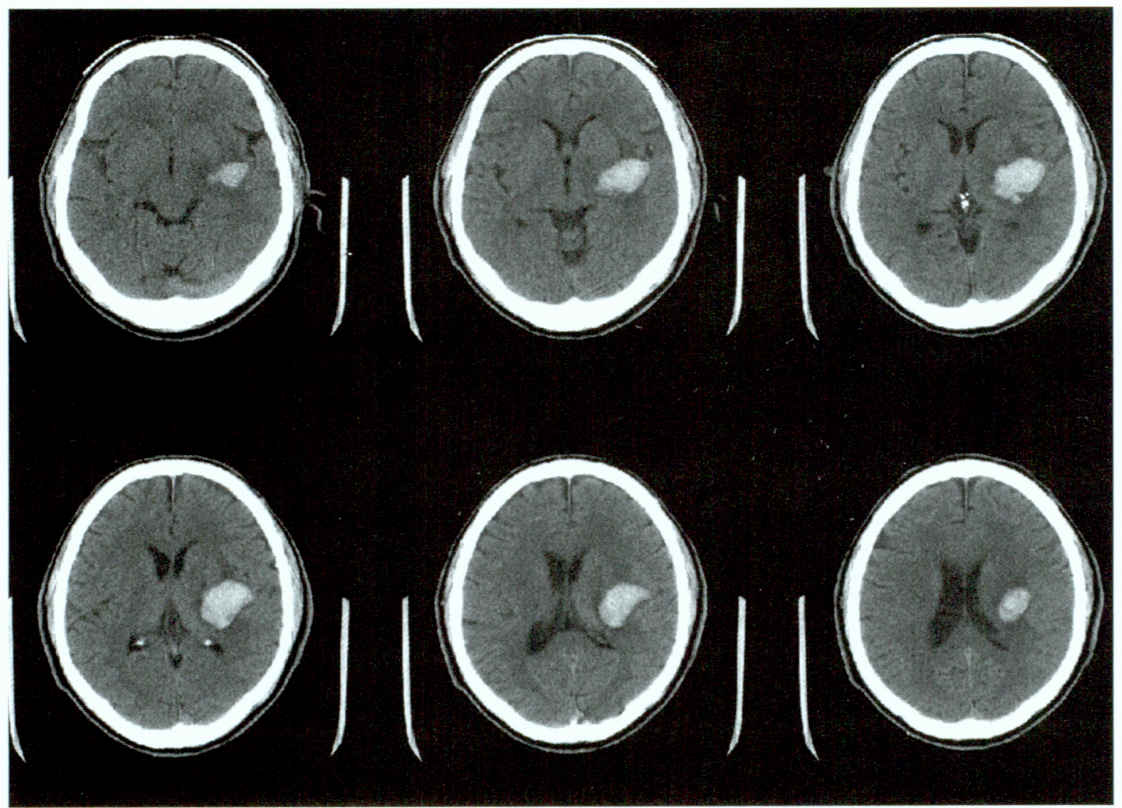

Fig. 7 Case 3 : The CT scan demonstrates a left putaminal hemorrhage at onset. This patient has severely impaired right hemiparesis.
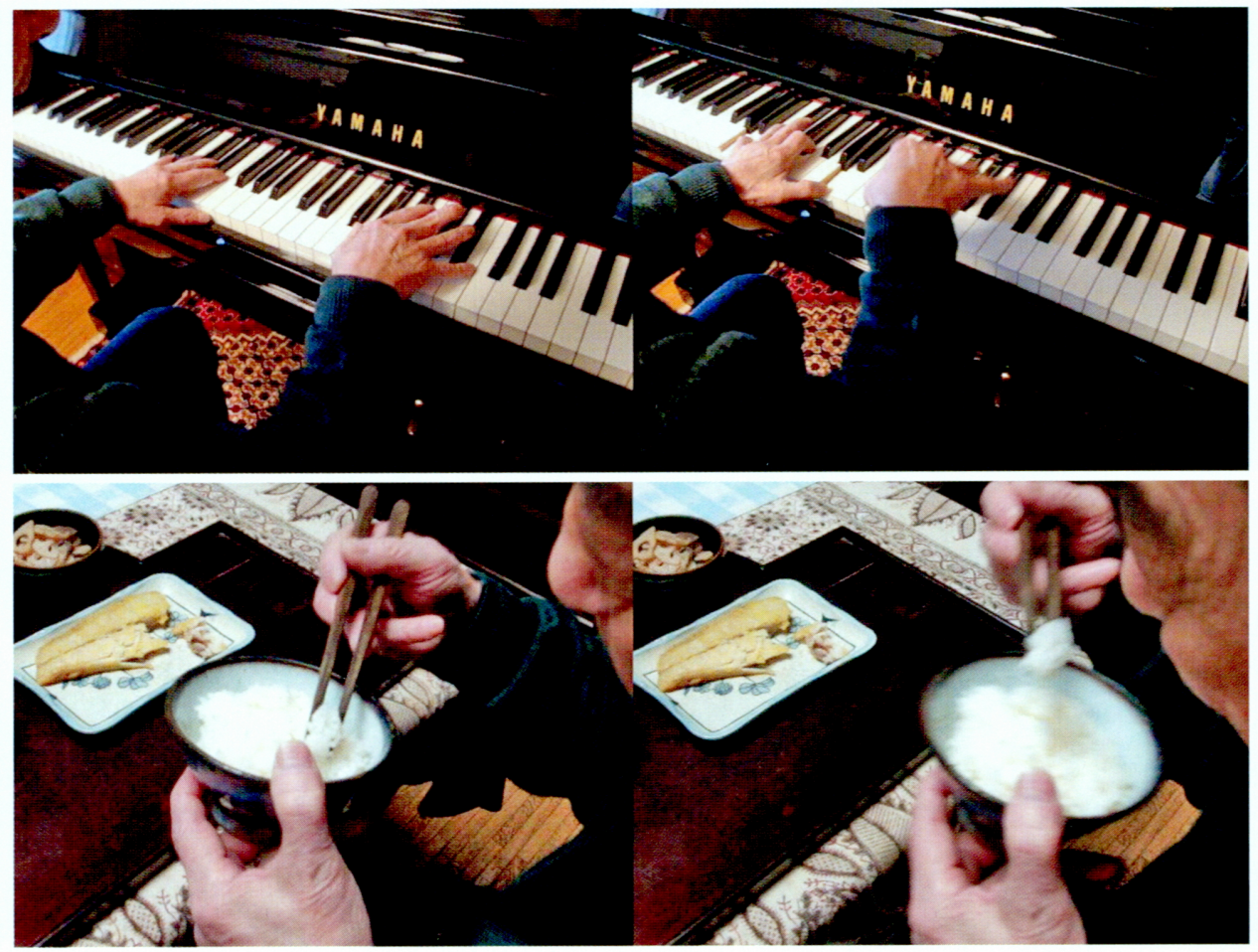

Fig. 8 Case 3 : The patient has acquired the functional ability of playing the piano (upper figures) and using chopsticks (lower figures) after NEURO-15 at 6 years after suffering a left putaminal hemorrhage. 
Table 1 Case 3 : Upper extremity function assessment on baseline and post-treatment (2-weeks) after NEURO-15.

\begin{tabular}{ccc}
\hline assessment & baseline & post-treatment (2-weeks) \\
\hline $\begin{array}{c}\text { Hemiparesis recover } \\
\text { grade of 12-grade assess- } \\
\text { ment }\end{array}$ & Arm 11, Hand 10 & Arm 12, Hand 11 \\
$\begin{array}{c}\text { Fugl-Meyer assessment } \\
\text { (upper extremity) }\end{array}$ & $59 / 66$ & $64 / 66$ \\
$\begin{array}{c}\text { Simple test of evaluation } \\
\text { of hand function (STEF) } \\
\text { Wolf motor function test } \\
\text { performance time }\end{array}$ & $86 / 100$ & $89 / 100$ \\
WMF functional ability \\
scale
\end{tabular}

Fig. 7 と Fig. 8，それに Table 1 は 6 年前発症の左被款 出血後右片麻痺の慢性期例に対する Neuro-15 施行前後 の成績を提示した，右上肢機能は 12 段階回復グレード 評価 ${ }^{40)}$ にて施行前上肢 11 , 手指 10 と分離段階ではあっ たが，右手での箸使用などの巧緻性動作の改善には達し ていなかった. Neuro-15 施行後, 上肢手指機能評価では Table 1 のごとく改善し, 右手でのピアノ演奏と箸使用が 可能となった.

Table 1 で示した上肢手指の評価法であるが，12 段階 回復グレード評価は上田らにより標準化された脳卒中片 麻痺上肢手指の評価法であり，0（完全麻痺）～12（ス ピードテストで健側の 1.5 倍以下までの改善）までの細 分化された評価法である ${ }^{40)}$. Fugl-Meyer assessment は 国際的に使用されている脳卒中上下肢機能の評価法であ り，上肢機能の最良スコアは 66 点である ${ }^{11)}$. STEF はわ が国で標準化されている簡易上肢機能テストであり最良 スコアは 100 点である ${ }^{38)}$. Wolf motor function test も国 際的に沉用されている上肢機能評価法であり，15 項目の 動作を遂行できる時間 performance time と, その達成能 力 functional ability scale（最良スコア75）でもつて評価 する ${ }^{37) 44)}$. Case 3 ではこのような上肢手指機能評価法ス コアのいずれにおいても改善が認められた。

Kakuda ら ${ }^{19)}$ は 204 例の Neuro-15 施行成績を分析し ており, Fugl-Meyer assessment $と$ Wolf motor function test performance time にて有意な改善をえたことを報告 している．また年齢と発症後の期間は治療成績には影響 しないことも特筆される。従来のリハビリテーションの みでは限界のあった脳卒中慢性期における上肢手指機能 改善をはかることが可能な新たな治療プログラムの登場 であると言える。

\section{まとめ}

今日までに明らかにされている脳可塑性理論に依拠し た脳卒中リハビリテーションについて述べた。急性期に おける critical time window の時期からの早期リハビリ テーション介入が必須であること, さらに急性期から慢 性期にかけてのステージ理諭に依拠したリハビリテー ションプログラムを選択し継続することが望ましい帰結 へとつなげることができる。

機能回復の阻害因子として, 急性期から生じるワー ラー変性と, さらに㽷縮の発現メカニズムについて述べ た。リハビリテーションの早期介入により痤縮を子防す ることと，早期からの㾏縮治療の重要性を指摘した。

脳梁を介する健側大脳半球運動野から患側大脳半球運 動野に対する抑制理論に依拠した経頭蓋磁気刺激と集中 作業療法のプログラムが, 従来のリハビリテーションの みでは不可能であつた上肢手指機能改善につながること を記した。

\section{文 献}

1）安保雅博, 角田 亘編著：rTMS と集中作業療法による 手指機能回復へのアプローチ。東京，三輪書店， 2010 .

2) Amirabdollahian F, Loureiro R, Gradwell E, Collin C, Harwin W, Johnson G: Multivariate analysis of the Fugl Meyer outcome measures assessing the effectiveness of GENTLE/S robot-mediated stroke therapy. $J$ Neuroeng Rehabil 4:4, 2007.

3) Barbay S, Plautz EJ, Friel KM, Frost SB, Dancause N, Stowe AM, Nudo RJ: Behavioral and neurophysiological effects of delayed training following a small ischemic infarct in primary motor cortex of squirrel monkeys. Exp Brain Res 169: 106-116, 2006.

4) Biernaskie J, Corbett D: Enriched rehabilitative training promotes improved forelimb motor function and enhanced dendritic growth after focal ischemic injury. $J$ Neurosci 
$21: 5272-5280,2001$.

5) Biernaskie J, Chernenko G, Corbett D : Efficacy of rehabilitative experience declines with time after focal ischemic brain injury. J Neurosci 24: 1245-1254, 2004.

6) Blennerhassett $J$, Dite W. Additional task-related practice improves mobility and upper limb function early after stroke: a randomized controlled trial. Aust J Physiother 50 : 219-224, 2004.

7) Boake C, Noser EA, Ro T: Constraint-induced movement therapy during early stroke rehabilitation. Neurorehabil Neural Repair 21: 14-24, 2007.

8) Chae J, Behoux F, Bohinc T, Dobos L, Davis T, Friedl A: Neuromuscular stimulation for upper extremity motor and functional recovery in acute hemiplegia. Stroke 29: 975979, 1998.

9) DeVetten G, Coutts SB, Hill MD, Goyal M, Eesa M, O'Brien B, Demchuk AM, Kirton A; MONITOR and VISION study groups: Acute corticospinal tract Wallerian degeneration is associated with stroke outcome. Stroke 41: 751-756, 2010.

10) Dromerick AW, Edwards DF, Hahn M: Does the application of constraint-induced movement therapy during acute rehabilitation reduce arm impairment after ischemic stroke? Stroke $31: 2984-2988,2000$.

11) Fugl-Meyer AR, Jääskö L, Leyman I, Olsson S, Steglind $\mathrm{S}$ : The post-stroke hemiplegic patient. 1. a method for evaluation of physical performance. Scand J Rehabil Med 7: 13-31, 1975.

12) Gracies JM : Pathophysiology of spastic paresis. I : Paresis and soft tissue change. Muscle Nerve 31:535-551, 2005.

13) Gracies JM : Pathophysiology of spastic paresis. II : Emergence of muscle overactivity. Muscle Nerve 31:552571,2005

14) Hakkennes S, Keating JL. Constrait-induced movement therapy following stroke: A systematic review of randomised controlled trials. Aust J Physiother 51:221-231, 2005.

15) Higgins J, Salbach NM, Wood-Dauphinee S, Richard CL, Cote R, Mayo NE. The effect of a task oriented intervention on arm function in people with stroke: a randomized controlled trial. Clin Rehabil 20:296-310, 2006.

16）細見雅史，島田憲二，松本憲二，竹林 崇，丸本浩平， 道免和久: Constraint-induced movement (CI 療法) の効 果と効果予測因子.リ八医学 49:23-30, 2012.

17) Hsu SS, Hu MH, Wang YH, Yip PK, Chiu JW, Hsieh CL: Dose-response relation between neuromuscular electrical stimulation and upper-extremity function in patients with stroke. Stroke 41:821-824, 2010.

18) Kakuda W, Abo M, Kobayashi K, Momosaki R, Yokoi A, Fukuda A, Ishikawa $\mathrm{A}$, Ito $\mathrm{H}$, Tominaga $\mathrm{A}$ : Low-frequency repetitive transcranial magnetic stimulation and intensive occupational therapy for poststroke patients with upper limb hemiparesis: preliminary study of a 15day protocol. Int J Rehabil Res $33:$ 339-345, 2010.

19) Kakuda W, Abo M, Shimizu M, Sasanuma J, Okamoto T, Yokoi A, Taguchi K, Mitani S, Harashima H, Urushidani N, Urashima M; NEURO Investigators: A multi-center study on low-frequency rTMS combined with intensive occupational therapy for upper limb hemiparesis in poststroke patients. J Neuroeng Rehabil 9:4, 2012.

20）烏野 大，千賀富士敏，太田厚美：高電圧パルス電流療
法一High Voltage Current Therapy一. 理学療法のあゆ み $15: 27-40,2004$.

21) Kleim JA, Barbay $S$, Nudo RJ: Functional reorganization of the rat motor cortex following motor skill learning. $J$ Neurophysiol 80:3321-3325, 1998.

22) Könönen M, Tarkka IM, Niskanen E, Pihlajamäki M, Mervaala E, Pitkänen K, Vanninen R: Functional MRI and motor behavioral changes obtained with constraintinduced movement therapy in chronic stroke. Eur J Neurol 19:578-586, 2012.

23) Kuhn MJ, Johnson KA, Davis KR. Wallerian degeneration: evaluation with MR imaging. Radiology 168:199-202, 1988.

24) Kwakkel G, Wagenaar RC, Koelman TW, Lankhorst GJ, Koetsier JC: Effects of intensity of rehabilitation after stroke. Stroke 28:1550-1556, 1997.

25) Langhorne P, Coupar F, Pollock A: Motor recovery after stroke: a systematic review. Lancet Neurol 8:741-754, 2009.

26) Matsusue E, Sugihara S, Fujii S, Kinoshita T, Ohama E, Ogawa T. Wallerian degeneration of the corticospinal tracts: postmortem MR-pathologic correlations. Acta Radiol 48: 690-694, 2007.

27) Michielsen ME, Selles RW, van der Geest JN, Eckhardt M, Yavuzer G, Stam HJ, Smits M, Ribbers GM, Bussmann JB : Motor recovery and cortical reorganization after mirror therapy in chronic stroke patients: a phase II randomized controlled trial. Neurorehabil Neural Repair 25: 223-233, 2011.

28) Molina-Luna K, Hertler B, Buitrago MM, Luft AR: Motor learning transiently changes cortical somatotopy. NeuroImage 40:1748-1754, 2008.

29) Nudo RJ, Milliken GW, Jenkins WM, Merzenich MM: Use-dependent alterations of movement representations in primary motor cortex of adult squirrel monkeys. $J \mathrm{Neu}$ rosci 16: 785-807, 1996.

30) Nudo RJ, Milliken GW : Reorganization of movement representations in primary motor cortex following focal ischemic infarcts in adult squirrel monkeys. $J$ Neurophysiol 75: 2144-2149, 1996.

31) Nudo RJ, Wise BM, SiFuentes F, Milliken GW: Neural substrates for the effects of rehabilitative training on motor recovery after ischemic infarct. Science 272: 1791-1794, 1996.

32) Pascual-Leone A, Nguyet D, Cohen LG, Brasil-Neto JP, Cammarota A, Hallett $\mathrm{M}$ : Modulation of muscle responses evoked by transcranial magnetic stimulation during the acquisition of new fine motor skills. J Neurophysiol 74: 1037-1045, 1995.

33) Ramachandran VS, Altschuler EL: The use visual feedback, in particular mirror visual feedback, in restoring brain function. Brain 132: 1693-1710, 2009.

34) Shaw L, Rodgers H, Price C, van Wijck F, Shackley P, Steen N, Barnes M, Ford G, Graham L; BoTULS investigators: BoTULS: a multicentre randomised controlled trial to evaluate the clinical effectiveness and cost-effectiveness of treating upper limb spasticity due to stroke with botulinum toxin type A. Health Technol Assess 14: 1-113, 2010.

35）篠原幸人, 小川 章, 鈴木則宏, 片山泰朗, 木村彰男編： 脳卒中治療ガイドライン 2009, 東京, 協和企画, 2009, pp.308-312. 
36) Swayne OB, Rothwell JC, Ward NS, Greenwood RJ: Stages of motor output reorganization after hemispheric stroke suggested by longitudinal studies of cortical physiology. Cereb Cortex 18: 1909-1922, 2008.

37）高橋香代子。道免和久, 佐野恭子, 竹林 崇, 蜂須賀研 二，木村哲彦：新しい上肢運動機能評価法 -日本版 Wolf Motor Function Test の信頼性と妥当性．総合リ八 36 ： 797-803, 2008.

38）寺田千秀：簡易上肢機能検査（STEF）。 OT ジャーナル 38: 681-686, 2004.

39) Timmermans AA, Spooren AI, Kingma H, Seelen HA. Influence of task-oriented training content on skilled armhand performance in stroke: a systematic review. Neurorehabil Neural Repair 24:858-870, 2010.

40）上田 敏, 長谷川恒雄, 安藤一也, 佐久間昭, 楠 正： 片麻痺手指機能テストの標準化-12 段階手指機能テス 卜および 5 段階上肢能力テスト一. リ八医学 $22: 143-$ 160, 1985.

41) Wagenaar RC, Meyer OG. Effects of stroke rehabilitation, I : a critical review of the literature. J Rehabil Sci 4: 61-73, 1991.
42) Wagenaar RC, Meyer OG. Effects of stroke rehabilitation, II : a critical review of the literature. J Rehabil Sci 4 : 97-109, 1991.

43) Ward NS, Cohen LG: Mechanisms underlying recovery of motor function after stroke. Arch Neurol 61:1844$1848,2004$.

44) Wolf SL, Catlin PA, Ellis M, Archer AL, Morgan B, Piacentino A : Assessing Wolf motor function test as outcome measure for research in patients after stroke. Stroke 32: 1635-1639, 2001.

45) Wolf SL, Winstein CJ, Miller JP, Taub E, Uswatte G, Morris D, Giuliani C, Light KE, Nichols-Larsen D; EXCITE Investigators: Effect of constraint-induced movement therapy on upper extremity function 3 to 9 months after stroke: the EXCITE randomized clinical trial. JAMA 296 : 2095-2104, 2006.

46) Yavuzer G, Selles R, Sezer N, Sütbeyaz S, Bussmann JB, Köseoğlu F, Atay MB, Stam HJ : Mirror therapy improves hand function in subacute stroke: a randomized controlled trial. Arch Phys Med Rehabil $89:$ 393-398, 2008.

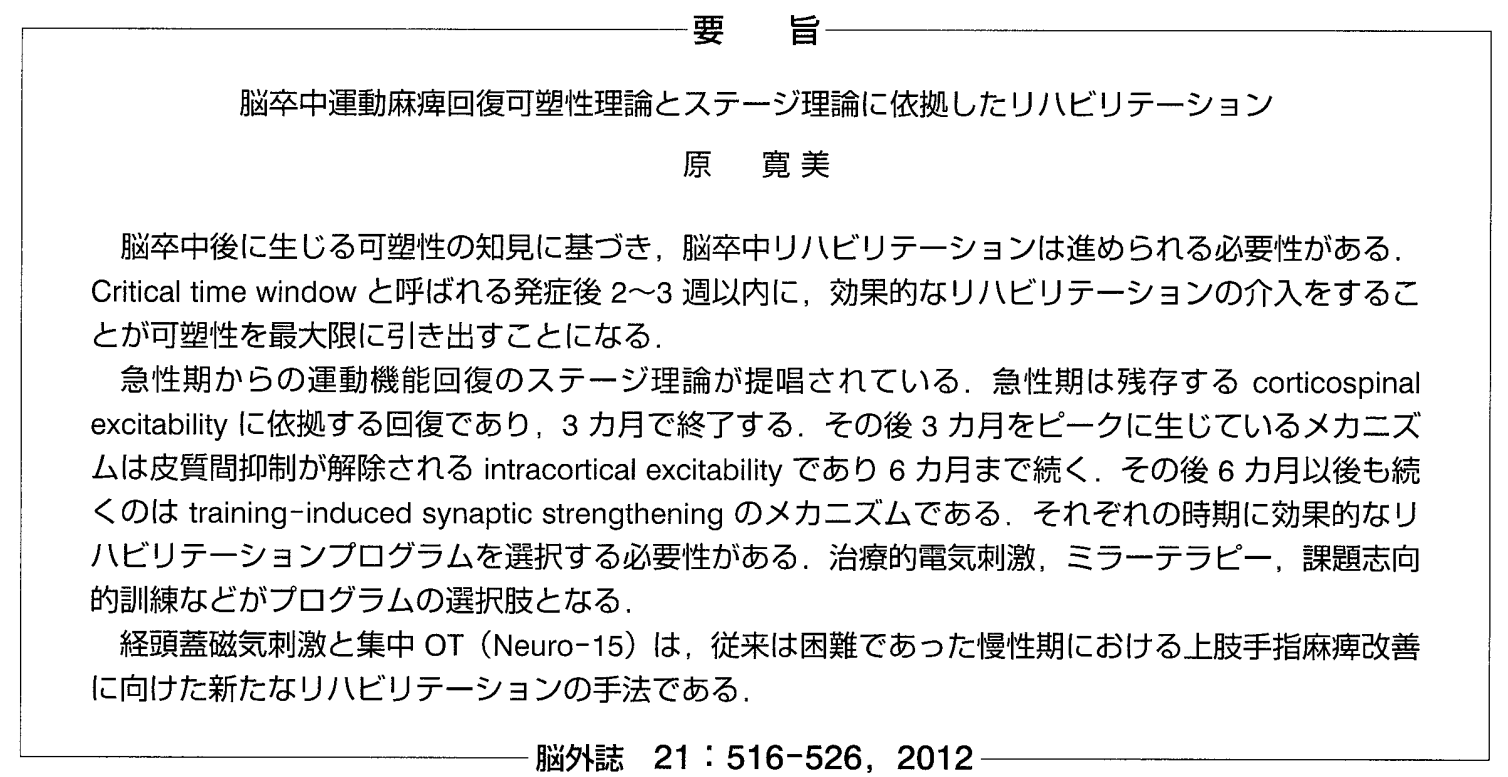

